DOI: https://doi.org/10.12797/Politeja.15.2018.54.07

Tomasz KUBIN

Uniwersytet Śląski w Katowicach

tomasz.kubin@us.edu.pl

\title{
ZNACZENIE EUROPEJSKIEJ INICJATYWY OBYWATELSKIEJ W KONTEKŚCIE DEFICYTU DEMOKRACJI W UNII EUROPEJSKIEJ
}

ABSTRACT The importance of the European citizens' initiative in the context of democratic deficit in the European Union

One of the instruments introduced into EU law on the basis of the Treaty of Lisbon for the first time, aimed at strengthening the democratic legitimacy of the functioning of the EU, is the European citizens' initiative (ECI). The regulation on the ECI was adopted and entered into force in 2011 and started to apply from 1 April 2012. It seems, that almost six years of the functioning of the ECI is a sufficient period of time to try to assess its meaning to strengthen the democratic legitimacy of the functioning of the EU. The main aim of the study is to answer the question: whether, taking into account the experiences of the ECI, the European citizens' initiative contributed to reducing the democratic deficit in the EU and thus to strengthening the legitimization of the European Union institutions and the EU as a whole. The article indicates the objectives of the ECI, which would allow to reduce the democratic deficit in the EU and strengthen the legitimacy of this organization. The most important data illustrating the functioning of the EIO were also presented. The next part of the article is the analysis and assessment of the importance of the ECI in reducing the democracy deficit and strengthening the legitimacy of the EU. The conclusions are included in the summary.

Keywords: European citizens' initiative, democracy deficit, European Union

Słowa kluczowe: europejska inicjatywa obywatelska, deficyt demokracji, Unia Europejska 


\section{WPROWADZENIE}

Ze względu na swoją specyfikę i cechy zarówno typowej organizacji międzynarodowej o charakterze międzyrządowym, organizacji ponadnarodowej, jak i państwa, Unia Europejska jest podmiotem, w odniesieniu do którego porusza się zagadnienie legitymizacji funkcjonowania jej samej i jej systemu instytucjonalnego ${ }^{1}$. Od mniej więcej pierwszej połowy lat 90. XX w. w literaturze przedmiotu powszechnie wskazuje się, że legitymacja demokratyczna UE i jej instytucji jest zbyt słaba, choć warunkiem członkostwa w UE jest funkcjonowanie w danym państwie demokratycznego systemu politycznego, a demokracja jest jedną z wymienionych w art. 2 TUE ${ }^{2}$ wartości, na których opiera się UE. Uważa się, że chociaż UE sama ubiera się w retorykę demokracji - fundamentalny wymóg dla panstw cztonkowskich - sama jest okryta ledwie skąpym demokratycznym listkiem figowym ${ }^{3}$. W rezultacie wzmocnienie legitymacji swoich instytucji stało się od lat 90. XX w. jednym z najważniejszych wyzwań UE.

Wzmocnienie demokracji w UE było celem od początku towarzyszącym pracom nad traktatem ustanawiającym Konstytucję dla Europy (TKE) ${ }^{4}$. Po fiasku ratyfikacji tego traktatu większość jego postanowień wprowadzono do podpisanego 13 grudnia 2007 r. traktatu z Lizbony ${ }^{5}$ (TL), który wszedł w życie 1 grudnia 2009 r. Jednym z instrumentów wprowadzonych po raz pierwszy do prawa UE, mających na celu wzmocnienie demokratycznej legitymacji funkcjonowania UE, jest europejska inicjatywa obywatelska (EIO). Wydaje się, że prawie sześć lat funkcjonowania EIO to okres wystarczający na próbę oceny jej znaczenia dla wzmocnienia demokratycznej legitymacji funkcjonowania UE.

Głównym celem opracowania jest weryfikacja/falsyfikacja następującej hipotezy: europejska inicjatywa obywatelska przyczyniła się do zmniejszenia deficytu demokracji w UE i w ten sposób wzmocnienia legitymacji instytucji Unii Europejskiej i Unii w ogóle. Przedmiotem badania są zatem rezultaty dotychczasowego funkcjonowania EIO. W drugiej części opracowania wskazano założenia i cele EIO, które miałyby umożliwić zmniejszenie deficytu demokracji w UE i wzmocnienie legitymacji tej organizacji, oraz przedstawiono najważniejsze dane i informacje na temat dotychczasowego funkcjonowania EIO. Analiza i ocena znaczenia tego rozwiązania dla redukcji deficytu

T. Kubin, Legitymizacja systemu instytucjonalnego Unii Europejskiej, Katowice 2014, s. 58-62.

Traktat o Unii Europejskiej (wersja skonsolidowana), Dz.U. UE C 202, 7 VI 2016.

3 R. Bellamy, D. Castiglione, The Uses of Democracy. Reflections on the European Democratic Deficit, [w: ] Democracy in the European Union. Integration Through Deliberation?, red. E.O. Eriksen, J.E. Fossum, London-New York 2000, s. 65.

4 T. Kubin, Postanowienia Traktatu Lizbońskiego a zagadnienie "deficytu demokracji” $w$ Unii Europejskiej, „Studia Europejskie” 2010, nr 3, s. 10; V. Cuesta Lopez, The Lisbon Treaty's Provisions on Democratic Principles: A Legal Framework for Participatory Democracy, „European Public Law” 2010, vol. 16, nr 1, s. 125-127.

5 Traktat z Lizbony zmieniający Traktat o Unii Europejskiej i Traktat ustanawiajacy Wspólnotę Europejska, Dz.U. UE C 306, 17 XII 2007. 
demokracji i wzmocnienia legitymacji UE stanowi treść części trzeciej artykułu. Najważniejsze wnioski zawarto w podsumowaniu.

Aby osiągnąć wskazany cel, w artykule wykorzystano dane dotyczące EIO zawarte na stronie internetowej Komisji Europejskiej, poddaną selekcji i krytycznej analizie literaturę przedmiotu dotyczącą EIO oraz odpowiednie akty prawne i inne dokumenty.

\section{ZAŁOŻENIA I CELE EUROPEJSKIEJ INICJATYWY OBYWATELSKIEJ. EIO W PRAKTYCE}

Postanowienia o europejskiej inicjatywie obywatelskiej znalazły się już w art. I-47(4) Traktatu ustanawiającego Konstytucję dla Europy ${ }^{6}$. Jak wspomniano, wobec niepowodzenia jego ratyfikacji większość jego regulacji wprowadzono do traktatu z Lizbony. Dotyczyło to m.in. treści artykułu dotyczącego EIO, który został powtórzony w TL właściwie w takim samym brzmieniu.

Na podstawie zmian wprowadzonych na mocy TL do Traktatu o Unii Europejskiej (TUE) ogólną podstawę prawną EIO stanowi art. 11(4) TUE. W artykule tym stwierdzono m.in., że procedury i warunki wymagane w celu przedstawienia EIO, określone w rozporządzeniach przyjmowanych w zgodzie ze zwykłą procedurą ustawodawczą, są zgodne $\mathrm{z}$ art. $24 \mathrm{TFUE}^{7}$.

Prace legislacyjne instytucji UE nad rozporządzeniem regulującym szczegółowo warunki i procedury EIO rozpoczęły się w $2009 \mathrm{r}$. Ich rezultatem jest ostateczna wersja rozporządzenia $(211 / 2011)$ w sprawie $\mathrm{EIO}^{8}$. Zgodnie z jego art. 23 weszło ono w życie 31 marca 2011 r., a zaczęło być stosowane od 1 kwietnia 2012 r. ${ }^{9}$ Kilka miesięcy po przyjęciu tego rozporządzenia uregulowano szczegóły techniczne dotyczące zbierania deklaracji poparcia EIO elektronicznie ${ }^{10}$; inne wymogi związane z EIO (np. minimalna liczba sygnatariuszy popierających EIO przypadających na dane państwo UE, informacje wymagane w celu zarejestrowania EIO, wzór formularza deklaracji poparcia EIO)

\footnotetext{
Traktat ustanawiający Konstytucję dla Europy, Dz.U. UE C 310, 16 XII 2004.

Traktat o funkcjonowaniu Unii Europejskiej...
}

8 Rozporzadzenie Parlamentu Europejskiego i Rady (UE) nr 211/2011 z dnia 16 lutego $2011 \mathrm{r}$. w sprawie inicjatywy obywatelskiej, Dz.U. UE L 65, 11 III 2011. Na temat procedury legislacyjnej tego rozporządzenia zob. np. M. Witkowska, Regulacja europejskiej inicjatywy obywatelskiej przyktadem oddziatywania spoteczeństwa obywatelskiego w Unii Europejskiej, [w:] Europa dla mtodych - szansa ou d'illusion, red. A. Olejniczak, Ł. Zamęcki, Warszawa 2013, s. 27-35.

9 Szerzej na temat dyskusji nad treścią rozporządzenia 211/2011 zob. J. Barcz, Inicjatywa obywatelska aspekty prawne i instytucjonalne, „Europejski Przegląd Sądowy” 2011, nr 10, s. 16-26; D. Szeligowska, E. Mincheva, The European Citizens' Initiative - Empowering European Citizens within the Institutional Triangle: A Political and Legal Analysis, „Perspectives on European Politics and Society” 2012, vol. 13, nr 3, s. 270-284, [online] https://doi.org/10.1080/15705854.2012.702572.

10 Rozporzadzenie wykonawcze Komisji (UE) nr 1179/2011 z dnia 17 listopada 2011 r. ustanawiajace specyfikacje techniczne $w$ odniesieniu do systemów zbierania deklaracji on-line na mocy rozporzadzenia Parlamentu Europejskiego i Rady (UE) nr 211/2011 w sprawie inicjatywy obywatelskiej, Dz.U. UE L 301, 18 XI 2011. 
zawarte w załącznikach do rozporządzenia 211/2011 były następnie zmieniane (aktualizowane) w rozporządzeniach delegowanych $\mathrm{KE}^{11}$.

Europejska inicjatywa obywatelska to jeden $\mathrm{z}$ instrumentów wprowadzonych do prawa UE na mocy TL i mających wzmocnić demokratyczną legitymację UE ${ }^{12}$. Stanowi ona jedną z form uczestnictwa obywateli państw UE w jej życiu demokratycznym; mają oni do tego prawo na podstawie art. 10(3) TUE. Inne możliwości zaangażowania obywateli w funkcjonowanie UE to m.in.: prawo do głosowania i do kandydowania w wyborach do PE (art. 14 TUE oraz art. 39 Karty Praw Podstawowych - KPP), prawo do składania petycji do PE (zgodnie z art. 24 TFUE i art. $44 \mathrm{KPP}$, w trybie art. 227 TFUE), prawo do zwracania się do Rzecznika Praw Obywatelskich UE (w trybie art. 228 TFUE; prawo to powtórzono w art. $43 \mathrm{KPP}$ ), prawo do pisemnego zwracania się każdej instytucji i organu UE określonego w art. 24 TFUE lub w art. 13 TUE w jednym z języków urzędowych UE i otrzymywania odpowiedzi w tym samym języku. Na podstawie art. $42 \mathrm{KPP}$ obywatele UE mają również prawo do dostępu do dokumentów instytucji, organów i jednostek organizacyjnych UE.

EIO stwarza obywatelom UE możliwość bezpośredniego zwrócenia się do KE o to, aby instytucja ta przedłożyła propozycję aktu prawnego UE mającego na celu realizację celów zawartych w TUE i TFUE. Jest więc instrumentem podobnym do prawa PE (art. 225 TFUE) oraz prawa Rady (art. 241 TFUE).

Biorąc pod uwagę wskazywane w literaturze przedmiotu przejawy deficytu demokracji w UE ${ }^{13}$, postanowienia traktatów oraz genezę i treść rozporządzenia $211 / 2011^{14}$, wśród celów EIO można wskazać:

- wzmocnienie demokracji na poziomie UE, redukcję tzw. deficytu demokracji w UE i wzmocnienie w ten sposób legitymacji funkcjonowania UE i jej systemu instytucjonalnego;

- wzmocnienie poczucia wpływu obywateli na funkcjonowanie UE, „zbliżenie" UE do obywateli i wyjście z dyskusją na tematy dotyczące UE poza schemat, w którym „Bruksela debatuje z Brukselą,, tzn. poza instytucje i organy samej UE;

- uzupełnienie katalogu praw obywatelskich związanych z obywatelstwem UE $\mathrm{i}$ ich wzmocnienie;

11 Rozporządzenia delegowane Komisji (UE): nr 268/2012 z 25 I 2012, nr 887/2013 z 11 VII 2013, nr 531/2014 z 12 III 2014, nr 2015/1070 z 31 III 2015.

12 T. Kubin, Postanowienia Traktatu Lizbońskiego..., s. 9-30.

13 Tenże, Legitymizacja systemu..., s. 62-69.

14 J. Barcz, Inicjatywa obywatelska..., s. 16-17; V. Cuesta Lopez, The Lisbon Treaty's Provisions..., s. 136-137; L. Bouza Garcia, J. Greenwood, Introduction, „Perspectives on European Politics and Society” 2012, vol. 13, nr 3, s. 251-252, [online] https://doi.org/10.1080/15705854.2012.702570; L. Bouza Garcia, S. Del Río Villar, The ECI as a Democratic Innovation: Analysing its Ability to Promote Inclusion, Empowerment and Responsiveness in European Civil Society, „Perspectives on European Politics and Society” 2012, vol. 13, nr 3, s. 313-316, [online] https://doi.org/10.1080/15705854.2012. 702575; R. Hrbek, National and European Political Parties and the European Citizens' Initiative, „Perspectives on European Politics and Society" 2012, vol. 13, nr 3, s. 370, [online] https://doi.org/10. 1080/15705854.2012.702579. 
- przyczynienie się do wzmocnienia poczucia tożsamości obywateli z UE;

- zwiększenie partycypacji politycznej obywateli dzięki włączeniu w proces podejmowania decyzji aktorów, którzy do tej pory nie byli w niego zaangażowani, i wzmocnienie w ten sposób zaangażowania obywateli UE w funkcjonowanie tej organizacji;

- przyczynienie się do wzmocnienia społeczeństwa obywatelskiego, przestrzeni (sceny) publicznej (politycznej) na poziomie UE i unijnego „rynku politycznego";

- przyczynienie się do integracji obywateli państw UE współpracujących na rzecz EIO;

- przyczynienie się do wzrostu wiedzy mieszkańców państw UE na temat Unii i jej funkcjonowania.

Jak wspomniano, rozporządzenie 211/2011 jest stosowane od 1 kwietnia 2012 r. Od tego czasu do marca 2018 r. podjęto kilkadziesiąt prób mających na celu przeprowadzenie EIO. Dane na ten temat zawarto w tab. 1.

Tab. 1. Funkcjonowanie EIO w praktyce (stan na 11 III 2018)

\section{Kategoria EIO pod względem formalnym}

EIO nieprzyjęte do rejestracji (ze względu na niespełnianie warunków określonych w art. 4 ust. 2 rozporządzenia ws. EIO)

EIO, które w ciągu roku nie uzyskały wystarczającego poparcia

EIO wycofane przez organizatorów

EIO zakończone sukcesem (takie, w których zebrano wystarczające poparcie)

EIO trwające

\section{Liczba EIO}

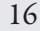

23

14

4

7

Źródło: opracowanie własne na podstawie danych i informacji zawartych na stronie http://ec.europa.eu/ citizens-initiative/public/welcome, 11 III 2018.

Jeśli za kryterium sukcesu EIO przyjąć jej zarejestrowanie oraz zebranie w ciągu 12 miesięcy odpowiedniego, określonego w rozporządzeniu 211/2011 poparcia, to dotychczas sukcesem zakończyły się 4 inicjatywy.

Pierwsza z nich to „Dostęp do wody i kanalizacji jest prawem człowieka! Woda jest dobrem publicznym, nie towarem!". Celem tej EIO było, aby prawo stanowione na poziomie UE zobowiązato rządy poszczególnych państw do zapewnienia dostępu i dostarczenia wszystkim mieszkańcom odpowiedniej ilości czystej wody pitnej oraz urządzeń sanitarnych. Zdaniem pomysłodawców tej EIO woda oraz zarządzanie zasobami wodnymi nie powinny podlegać zasadom rynku wewnętrznego i powinny być wyłączone spod mechanizmów wolnorynkowych. Poza tym UE powinna zwiększyć wysitki w celu osiagnięcia powszechnego dostępu do wody $i$ kanalizacji ${ }^{15}$.

15 Europejska Inicjatywa Obywatelska, Dostęp do wody i kanalizacji jest prawem cztowieka! Woda jest dobrem publicznym, nie towarem!, [online] http://ec.europa.eu/citizens-initiative/public/initiatives/ successful/details/2012/000003, 2 XII 2017. 
Inicjatywa ta została poparta łącznie przez 1680285 osób, przy czym minimalny próg poparcia osiągnięto w 13 państwach $\mathrm{UE}^{16}$. Rekcja KE była pozytywna. W swoim komunikacie stwierdziła, że $z$ zadowoleniem przyjmuje mobilizacje obywateli UE w celu wsparcia dostępu do bezpiecznej wody pitnej i infrastruktury sanitarnej w Europie ina świecie. [...] Na szczeblu UE Komisja będzie wykorzystywać zrealizowane już dziatania oraz nadal rozszerzać i utatwiać dostęp do bezpiecznej wody pitnej i infrastruktury sanitarnej dla catej ludności za pośrednictwem polityki ochrony środowiska i finansowania infrastruktury ${ }^{17}$.

EIO dotyczącą dostępu do czystej wody można więc uznać za zakończoną powodzeniem nie tylko w sensie formalnym, lecz także w wymiarze praktycznym. KE przyjęła tę EIO i podjęła szereg konkretnych działań w związku z jej celami ${ }^{18}$.

Druga EIO, w przypadku której udało się zebrać wymagane poparcie, to inicjatywa "Jeden z nas". Celem jej inicjatorów było, aby UE zakazata $i$ zakończyta finansowanie aktywności, które implikuja niszczenie ludzkich embrionów, w szczególności w obszarach badań, rozwoju izdrowia publicznego ${ }^{19}$.

Tę EIO poparło 1721626 osób, przy czym minimalne poparcie osiągnięto w 18 państwach $U^{20}$. Jednak w komunikacie przyjętym 28 maja 2014 r. Komisja stwierdziła, że nie widzi potrzeby zmian w regulacjach dotyczących finansowania badań nad przedmiotem EIO. W kwestii badań naukowych nad ludzkimi zarodkowymi komórkami macierzystymi KE uznała, że nie ma powodu do podejmowania konkretnych działań. Według niej istota tej EIO była niedawno przedmiotem dyskusji państw członkowskich i w PE, w wyniku której zdecydowano o kierunku polityki UE w tej sprawie $^{21}$. W związku z tym KE nie podjęła żadnych działań następczych ${ }^{22}$.

Trzecia EIO z odpowiednim poparciem to inicjatywa „Stop Wiwisekcji”. Jej celem było stworzenie ram prawnych na poziomie UE, dzięki którym zlikwidowano by doświadczenia na zwierzętach. Pomysłodawcy wzywali KE do unieważnienia dyrektywy 2010/63/UE w sprawie ochrony zwierząt wykorzystywanych do celów naukowych oraz do przedłożenia nowej propozycji, na mocy której zniesiono by eksperymenty na

16 Komisja Europejska, Zatacznik do komunikatu Komisji w sprawie europejskiej inicjatywy obywatelskiej "Dostęp do wody i kanalizacji jest prawem cztowieka! Woda jest dobrem publicznym, nie towarem!", Bruksela, 19 III 2014, COM(2014) 177 final, Annex 1, s. 4.

17 Komisja Europejska, Komunikat Komisji w sprawie europejskiej inicjatywy obywatelskiej „Dostęp do wody i kanalizacji jest prawem cztowieka! Woda jest dobrem publicznym, nie towarem!", Bruksela, 19 III 2014, $\operatorname{COM}(2014) 177$ final, s. 13.

18 Europejska Inicjatywa Obywatelska, Odpowiedź Komisji i dziatania następcze, [online] http://ec. europa.eu/citizens-initiative/public/initiatives/successful/details/follow-up/2012/000003/pl, 2 XII 2017.

19 Europejska Inicjatywa Obywatelska, Jeden $z$ nas, [online] http://ec.europa.eu/citizens-initiative/public/initiatives/successful/details/2012/000005, 2 XII 2017.

20 Komisja Europejska, Zatacznik do komunikatu Komisji w sprawie europejskiej inicjatywy obywatelskiej "Jeden z nas", Bruksela, 28 V 2014, COM(2014) 355 final, Annexes 1 to 5, s. 3.

21 Komisja Europejska, Komunikat Komisji w sprawie europejskiej inicjatywy obywatelskiej "Jeden z nas", Bruksela, 28 V 2014, COM(2014) 355 final, s. 19-22.

22 Europejska Inicjatywa Obywatelska, Stop Wiwisekcji, [online] http://ec.europa.eu/citizens-initiative/ public/initiatives/successful/details/follow-up/2012/000005/pl, 2 XII 2017. 
zwierzętach, wprowadzając w zamian obowiązek stosowania w badaniach biomedycznych i toksykologicznych danych odpowiednich dla ludzi ${ }^{23}$. Tę EIO poparło 1173130 osób, przy czym próg poparcia osiągnięto w 9 państwach $\mathrm{UE}^{24}$. KE $z$ zadowoleniem przyjęta mobilizacje obywateli na rzecz dobrostanu zwierząt, jednak stwierdziła m.in., że dążąc do ostatecznego celu, jakim jest całkowite zastąpienie zwierząt doświadczalnych, w dalszym ciągu niezbędnym narzędziem na szczeblu UE służącym ochronie tych zwierząt jest dyrektywa 2010/63/UE, której uchylenia domagali się inicjatorzy EIO. I $w$ zwiazku z tym Komisja nie zamierza przedstawić wniosku w sprawie uchylenia dyrektywy 2010/63/UE, ani nie zamierza zaproponować przyjęcia nowych ram prawnych ${ }^{25}$.

Czwarta EIO zakończona formalnym sukcesem dotyczyła wprowadzenia zakazu stosowania glifosatu oraz ochrony ludzi i środowiska przed toksycznymi pestycydami. Głównymi celami inicjatorów były: wprowadzenie zakazu stosowania środków chwastobójczych na bazie glifosatu, [...] zadbanie o to, by ocena naukowa pestycydów stużaca zatwierdzeniu regulacyjnemu przez UE opierata się wytacznie na opublikowanych badaniach zleconych przez wtaściwe organy publiczne, a nie przez sektor pestycydów oraz wytyczenie wiązacych celów ograniczenia stosowania pestycydów dla catej UE z myśla o zapewnieniu przysztości wolnej od pestycydów ${ }^{26}$.

Inicjatywę te poparło 1070865 osób, a minimalny próg został osiągnięty w 10 państwach $\mathrm{UE}^{27}$. W komunikacie przedstawionym w odpowiedzi na tę EIO Komisja stwierdziła, że nie ma podstaw (ani naukowych, ani prawnych) do wprowadzania zakazu stosowania glifosatu i w związku z tym nie przedłoży odpowiedniego wniosku mającego na celu zmianę istniejącego stanu prawnego w UE. Inaczej zareagowała na drugi postulat organizatorów: by ocena naukowa pestycydów mająca wpływ na treść regulacji prawnych przyjmowanych na poziomie UE opierała się wyłącznie na opublikowanych badaniach zleconych przez właściwe organy publiczne, a nie przez sektor pestycydów. Aby zwiększyć przejrzystość w tej sferze, KE zobowiązała się do przedłożenia wniosku ustawodawczego do maja 2018 r. Natomiast w odniesieniu do trzeciego postulatu KE stwierdziła, że zamierza skoncentrować się na wdrażaniu odpowiedniej dyrektywy (2009/128/EC) dotyczącej zrównoważonego stosowania pestycydów ${ }^{28}$.

23 Europejska Inicjatywa Obywatelska, Stop Wiwisekcji, [online] http://ec.europa.eu/citizens-initiative/ public/initiatives/successful/details/2012/000007, 2 XII 2017.

24 Komisja Europejska, Zatacznik do komunikatu Komisji w sprawie europejskiej inicjatywy obywatelskiej „Stop wiwisekcji”, Bruksela, 3 VI 2015, COM(2015) 3773 final, Annex 1, s. 3.

25 Komisja Europejska, Komunikat Komisji w sprawie europejskiej inicjatywy obywatelskiej „Stop wiwisekcji”, Bruksela, 3 VI 2015, C(2015) 3773 final, s. 10-11.

26 Europejska Inicjatywa Obywatelska, Zakaz stosowania glifosatu i ochrona ludzi i środowiska przed toksycznymi pestycydami, [online] http://ec.europa.eu/citizens-initiative/public/initiatives/successful/ details/2017/000002, 10 III 2018.

27 Komisja Europejska, Zatacznik do Komunikatu Komisji dotyczącego europejskiej inicjatywy obywatelskiej „Zakaz stosowania glifosatu i ochrona ludzi i środowiska przed toksycznymi pestycydami”, Strasburg, 12 XII 2017, C(2017)8414 final, Annex.

28 Komisja Europejska, Komunikat Komisji dotyczący europejskiej inicjatywy obywatelskiej „Zakaz stosowania glifosatu i ochrona ludzi i środowiska przed toksycznymi pestycydami”, Strasburg, 12 XII 2017, C(2017)8414 final, Annex. 


\section{ZNACZENIE EUROPEJSKIEJ INICJATYWY OBYWATELSKIEJ DLA ZMNIEJSZENIA DEFICYTU DEMOKRACJI W UNII EUROPEJSKIEJ}

EIO to pierwszy i jedyny jak do tej pory instrument demokracji bezpośredniej w organizacji międzynarodowej. Należy podkreślić, że EIO jest prawem nie do bezpośredniej inicjatywy prawodawczej, ale do zwrócenia się o taką inicjatywę do KE; to raczej obywatelski instrument inspiracji ustawodawczej ${ }^{29}$, umożliwiający zgłaszanie potrzeby przyjęcia jakichś regulacji prawnych, niż stricte instrument demokracji bezpośredniej. EIO jest zatem prawem inicjatywy pośredniej, co z perspektywy redukcji deficytu demokracji w UE można uznać za jedną z głównych słabości tego instrumentu. Z jednej strony takie rozwiązanie może być interpretowane jako wyraz swoistej „ostrożności” twórców TL czy nawet przejaw pewnej „nieufności” do obywateli państw UE. Z drugiej strony, biorąc pod uwagę np. to, że prawa bezpośredniej inicjatywy prawodawczej nie ma nawet PE, przyznanie go obywatelom byłoby krokiem bardzo daleko idącym i oznaczałoby koniec faktycznego monopolu KE na proponowanie aktów prawnych w UE, stanowiłoby więc dużą zmianę o charakterze ustrojowym w Unii.

Wydaje się, że liczba zarejestrowanych dotychczas EIO (48) jest dowodem, że konieczne do tego warunki określone w rozporządzeniu 211/2011 nie są nadmiernie skomplikowane i nie stanowią zbyt dużego utrudnienia; można uznać je za jasne i racjonalne. Wymóg struktury organizacyjnej EIO jest konieczny, ale jednocześnie sama inicjatywa jest bardzo prosta. Warunki, jakie musi spełnić, aby mogła zostać zarejestrowana (art. 4(2) rozporządzenia 211/2011), są uzasadnione, chociaż niektóre z nich są nieostre - zapewne można sobie wyobrazić spory dotyczące znaczenia określeń oczywiste nadużycie, oczywiście niepoważna lub dokuczliwa w odniesieniu do EIO. Nie może być ona także $w$ sposób oczywisty sprzeczna $z$ wartościami UE wymienionymi $\mathrm{w}$ art. 2 TUE, które również nie są precyzyjnie zdefiniowane. Brak wymogu kontroli EIO przez KE mógłby prowadzić do przedstawiania i zbierania poparcia dla inicjatyw, które nie mogą być przez UE zrealizowane, np. ze względów finansowych albo dlatego, że wykraczają poza kompetencje Unii. Kilkanaście EIO, które nie zostały zarejestrowane przez KE, potwierdza istnienie takiego ryzyka. Wyroki sądowe w przypadkach decyzji KE zaskarżonych do Trybunału Sprawiedliwości Unii Europejskiej (TSUE) potwierdziły stanowisko Komisji.

Przyznanie Komisji kompetencji związanych z kontrolą i przeprowadzaniem EIO, biorąc pod uwagę kompetencje i charakter polityczny instytucji UE, jest uzasadnione. Decyzja o odmowie rejestracji EIO musi być odpowiednio uzasadniona; KE musi także poinformować organizatorów o dostępnych środkach prawnych - przy czym nie zdefiniowano, o jakie środki może chodzić (art. 4(3) rozporządzania 211/2011). Praktyka dowodzi, że decyzje KE mogą być przedmiotem kontroli sądowej ze strony TSUE

29 M. Szewczyk, Kilka uwag na temat instytucji obywatelskiej inicjatywy prawodawczej $w$ Unii Europejskiej, „Przegląd Prawa Konstytucyjnego” 2012, nr 4, s. 108. 
(art. 263 TFUE) i zdarza się, że są one zaskarżane do TSUE. Przedmiotem skargi do TSUE może być rejestracja EIO przez KE lub komunikat Komisji ws. EIO. Czasami skargi organizatorów EIO na działania KE składane są do Europejskiego Rzecznika Praw Obywatelskich ${ }^{30}$. Nie ma natomiast możliwości wystąpienia na drogę sądową, jeśli KE odmawia wystąpienia $\mathrm{z}$ inicjatywą legislacyjną zaproponowaną w ramach EIO, co - jak wskazano - miało miejsce.

Minimalna liczba państw (siedem), z których muszą pochodzić popierający EIO, oraz ich liczba nie wydają się nadmiernie wygórowane i mogą zostać uznane za rozsądny kompromis pomiędzy odpowiednią reprezentatywnością a łatwością spełnienia warunku. Także 12 miesięcy na zebranie minimalnego poparcia dla EIO jest czasem relatywnie długim. $\mathrm{Z}$ porównania EIO z analogicznymi instrumentami demokracji bezpośredniej funkcjonującymi w państwach UE wynika, że minimalna liczba podpisów koniecznych przy EIO jest najniższa w relacji do ogółu populacji, a czas na zebranie podpisów - najdłuższy ${ }^{31}$. Przyjęta formuła definiowania liczby sygnatariuszy z danego państwa (iloczyn liczby posłów do PE i liczby 750) oznacza wykorzystanie zasady degresywnej proporcjonalności. To według niej miejsca w PE są rozdzielone pomiędzy państwa członkowskie UE, a w przeszłości przyznawano głosy ważone w Radzie. Oznacza to jednak, że „waga” głosu - a w przypadku EIO „waga” podpisu - obywateli poszczególnych państw UE nie jest taka sama.

Podmiotami odpowiedzialnymi za organizację EIO mogą być tylko osoby fizyczne, co poważnie ogranicza możliwość „zawłaszczania” czy upolityczniania EIO przez partie polityczne lub organizacje pozarządowe ${ }^{32}$. Taka decyzja ma zabezpieczyć EIO przed zawtaszczeniem przez lobbies ${ }^{33}$ oraz przyczynić się do rozwoju i wzmocnienia organizacji społeczeństwa obywatelskiego. Jak pokazują doświadczenia EIO, tego rodzaju podmioty rzeczywiście były w nie zaangażowane ${ }^{34}$. W praktyce trudno sobie wyobrazić, aby działania o zasięgu paneuropejskim były skutecznie podejmowane bez żadnych, przynajmniej minimalnie sformalizowanych organizacji. Jednak wymóg informowania o źródłach finansowania na pewno przyczynia się do większej przejrzystości EIO i ogranicza możliwość prób forsowania regulacji prawnych przez niejawnie finansujące je grupy interesu.

Fakt, że w ciągu niemal sześciu lat funkcjonowania EIO tylko cztery razy organizatorom udało się zebrać minimalną liczbę podpisów w przynajmniej siedmiu państwach UE (a w 23 przypadkach się to nie udało), nasuwa pytanie o przyczynę takiego stanu rzeczy. Do pewnego stopnia znaczenie mają zapewne praktyczne problemy związane

30 Na temat roli KE i Ombudsmana w EIO zob. N. Vogiatzis, Between Discretion and Control: Reflections on the Institutional Position of the Commission within the European Citizens'Initiative Process, „European Law Journal" 2017, vol. 23, nr 3-4, s. 250-271, [online] https://doi.org/10.1111/eulj.12229.

31 V. Cuesta-López, A Comparative Approach..., s. 261.

32 M. Szewczyk, Kilka uwag..., s. 102.

33 L. Bouza Garcia, J. Greenwood, Introduction..., s. 251-252.

34 J. Greenwood, The European Citizens' Initiative and EU Civil Society Organisations, „Perspectives on European Politics and Society" 2012, vol. 13, nr 3, s. 325-336, [online] https://doi.org/10.1080/157 05854.2012 .702576 . 
z procedurą rejestracji, zbierania podpisów i ich weryfikacji oraz przedkładania EIO Komisji Europejskiej. Wydaje się jednak, że to nie wymogi formalne są największą trudnością w funkcjonowaniu EIO. Jest nią problem z uzyskaniem odpowiedniego poparcia obywateli państw UE dla EIO. Należy podkreślić, że podpisy z poparciem EIO mogą być zbierane elektronicznie, a czas na ich zgromadzenie, jak wspomniano, można uznać za wystarczająco długi. Co więc może być powodem? Jedno z wyjaśnień to wymogi „techniczne” związane z udzieleniem poparcia EIO drogą elektroniczną. Dla pewnej grupy osób jest to zapewne przeszkodą. Można także postawić tezę, że kluczowe znaczenie mają tutaj takie czynniki, jak: bariera językowa, brak paneuropejskich mediów, wreszcie brak „rynku politycznego” obejmującego całą UE, a w konsekwencji trudności w informowaniu o EIO w państwach UE i w mobilizowaniu dla niej poparcia. Czyli to, co stanowi jeden z przejawów i jednocześnie jedną z przyczyn deficytu demokracji w UE.

Jednym z zakładanych celów EIO było zwiększenie wpływu obywateli na funkcjonowanie UE i na jej agendę. EIO powinna stymulować debaty na tematy dotyczące całej UE i o zasięgu ogólnoeuropejskim, a nie tylko narodowym, aktywizować obywateli państw UE i w ten sposób przyczyniać się do rozwoju paneuropejskiej przestrzeni politycznej i sceny politycznej oraz wzmacniać identyfikację z UE. Dotychczasowe doświadczenia EIO wskazują, że się to nie udało. EIO jest wykorzystywana najczęściej do prób przeprowadzenia inicjatyw legislacyjnych w sprawach relatywnie szczegółowych, wzbudzających zainteresowanie i dotyczących bezpośrednio interesów stosunkowo wąskich grup obywateli. Są to m.in. kwestie dotyczące ochrony środowiska, polityki społecznej, transportu - niewątpliwie są obiektywnie ważne, ale nie wzbudzają zbyt dużego zainteresowania i emocji szerszych grup społecznych, w związku z czym trudno przyciągnąć nimi zainteresowanie mediów ${ }^{35}$. Jedyna EIO zakończona faktycznym powodzeniem - w jej następstwie KE podjęła konkretne działania legislacyjne to ta dotycząca dostępu do wody i kanalizacji. Częściowo można za taką uznać także EIO w sprawie glifosatu. W przypadku pozostałych dwóch EIO, dla których udało się zebrać wymagane poparcie, KE nie podjęła działań legislacyjnych. Nie sposób więc stwierdzić, że dzięki EIO obywatele UE mają rzeczywisty wpływ na agendę Unii.

Miliony oddanych głosów w kilkudziesięciu EIO oznaczają, że instrument ten teoretycznie $\mathrm{w}$ pewnym stopniu zwiększa zaangażowanie obywateli w funkcjonowanie UE, a więc statystycznie partycypacja wzrosła. Siłą rzeczy EIO przyczynia się także do wzrostu wiedzy na temat UE i jej kompetencji. Należy jednak zwrócić uwagę na bardzo wyraźny spadek zainteresowania EIO. Biorąc pod uwagę wszystkie kategorie EIO pod względem formalnym (tab. 1), w 2012 r. podjęto działania zmierzające do rejestracji 26 inicjatyw, w 2013 r. - już tylko 13, w 2014 r. - 7, w 2015 r. - 5, w 2016 r. - 5, a w 2017 r. - 8. Można więc chyba postawić tezę, że po nadziejach związanych z EIO od razu po jej wprowadzeniu zainteresowanie tą formą partycypacji

35 Na ten temat zob. M. Błaszczuk-Zawiła, Czy europejska inicjatywa obywatelska ożywi debatę publiczna w UE?, „Unia Europejska.pl” 2012, nr 3, s. 11; M. Musiat-Karg, Europejska inicjatywa obywatelska uwagi na temat roli obywateli w procesie integracji europejskiej, „Rocznik Integracji Europejskiej” 2014, nr 8, s. 89 . 
politycznej w UE bardzo szybko osłabło i w ostatnich czterech latach ustabilizowało się na niskim poziomie.

Na pewno jedną z najważniejszych przyczyn tego zjawiska jest fakt, że EIO to procedura relatywnie wolna, a czas potrzebny na dostrzeżenie jej rezultatów może być bardzo długi. Na przeprowadzenie EIO potrzeba przynajmniej ok. 20 miesięcy (2 na zarejestrowanie, 1 na certyfikację systemu gromadzenia danych elektronicznie, 12 na zebranie podpisów, 3 na ich weryfikację, 3 na odpowiedź KE). Później ewentualnie następuje procedura prawodawcza, która może trwać kilka lat. Ponadto nawet przyjęcie aktu prawnego nie zawsze oznacza, że jego efekty będą widoczne od razu. Zatem na pełne rezultaty swoich działań inicjatorzy i sygnatariusze EIO muszą czekać bardzo długo, co trudno uznać za czynnik zachęcający do podejmowania inicjatywy.

$\mathrm{Na}$ jeszcze inny aspekt istotny w kontekście znaczenia EIO dla zmniejszenia deficytu demokracji zwraca uwagę Michał Szewczyk. Jego zdaniem stopień sformalizowania EIO jest nieproporcjonalnie duzy w stosunku do wptywu obywateli na dalsze losy swojego projektu prawodawczego, a obywatele, którzy zainicjowali EIO i ją poparli, w przypadku przedłożenia projektu aktu prawnego w następstwie EIO tracą możliwość wpływu na jego treść $\mathrm{w}$ trakcie prac legislacyjnych w UE, w tym także możliwość wycofania projektu. A przecież w trakcie prac legislacyjnych treść projektu aktu prawnego może zostać zasadniczo zmieniona i w rezultacie może mocno odbiegać od intencji inicjatorów $\mathrm{EIO}^{36}$.

Biorąc to pod uwagę, można postawić pytanie, czy np. wspomniane prawo do petycji do PE (art. 24 TFUE) nie jest instrumentem efektywniejszym w kontekście redukcji deficytu demokracji. Złożenie petycji do PE jest, w porównaniu do EIO, mniej sformalizowane, łatwiejsze i szybsze do przeprowadzenia. Nawet uwzględniając brak prawa PE do inicjatywy prawodawczej i dotychczasową praktykę EIO, porównanie koniecznych do zaangażowania sił i środków z potencjalnymi efektami petycji oraz EIO wypada raczej na korzyść tej pierwszej.

\section{PODSUMOWANIE I WNIOSKI}

Z przeprowadzonej konfrontacji zakładanych celów EIO z dotychczasowymi rezultatami jej funkcjonowania wynika, że instrument ten w znikomym stopniu przyczynił się do wzmocnienia demokracji i redukcji jej deficytu na poziomie UE. Zatem można stwierdzić, że postawiona we wstępie artykułu hipoteza badawcza została sfalsyfikowana.

EIO uzupełnia katalog praw obywatelskich związanych z obywatelstwem UE, ale nie sprawiła dotychczas, że obywatele UE mają większy wpływ na jej agendę. Fakt, że na przestrzeni ok. sześciu lat udało się zebrać wymagane poparcie tylko dla czterech EIO, sprawia, że trudno mówić o wyraźnym wzroście partycypacji i zaangażowania obywateli w sprawy UE. Nie sposób także wskazać na jakiś konkretny efekt wprowadzenia EIO w postaci zmian w prawie UE. Co więcej, już od drugiego roku funkcjonowania EIO

36 M. Szewczyk, Kilka uwag..., s. 106. 
widać bardzo wyraźny spadek zainteresowania tą możliwością zaangażowania się w sprawy UE; w latach 2014-2017 odnotowano tylko od pięciu do ośmiu prób podjęcia EIO.

Pod względem regulacji prawnych dotyczących EIO trudno o jakieś rewolucyjne zmiany, które pozwoliłby na jej wyraźne „ożywienie”. Wydaje się, że istota rzeczy leży gdzie indziej. Zgodnie z powszechnie akceptowaną prawdą instrumenty demokracji bezpośredniej lepiej działają w małych, homogenicznych wspólnotach ${ }^{37}$. W przypadku UE mamy do czynienia z bardzo dużą liczbą ludzi i ich znacznym zróżnicowaniem. Ponadto poczucie wspólnoty i tożsamości z UE jest relatywnie niskie. Brakuje też czegoś, co można by określić jako paneuropejska scena polityczna. EIO nie jest w stanie tego zmienić; natomiast te właśnie okoliczności w decydującej mierze wpływają na jej funkcjonowanie.

Doświadczenia z EIO mogą być sygnałem, że do takich pomysłów, jak ogólnoeuropejskie referenda czy wybory na stanowiska UE (np. przewodniczącego Rady Europejskiej, przewodniczącego KE czy posłów do PE z listy ogólnoeuropejskiej), trzeba podchodzić bardzo ostrożnie. Jeśli nie jest łatwo zebrać w tylko jednej czwartej państw UE po kilka-kilkadziesiąt tysięcy podpisów, to jak myśleć o paneuropejskich kampaniach wyborczych czy kandydatach, którzy mogliby być uznawani za reprezentujących interesy całej UE, a nie państw, z których pochodzą?

\section{BIBLIOGRAFIA}

Barcz J., Inicjatywa obywatelska - aspekty prawne i instytucjonalne, „Europejski Przegląd Sądowy" 2011, nr 10.

Bellamy R., Castiglione D., The Uses of Democracy. Reflections on the European Democratic Deficit, [w:] Democracy in the European Union. Integration Through Deliberation?, red. E.O. Eriksen, J.E. Fossum, London-New York 2000.

Błaszczuk-Zawiła M., Czy europejska inicjatywa obywatelska ożywi debate publiczna w UE?, „Unia Europejska.pl” 2012, nr 3.

Bouza Garcia L., Del Río Villar S., The ECI as a Democratic Innovation: Analysing its Ability to Promote Inclusion, Empowerment and Responsiveness in European Civil Society, „Perspectives on European Politics and Society" 2012, vol. 13, nr 3, [online] https://doi.org/10.1080/1 5705854.2012.702575.

Bouza Garcia L., Greenwood J., Introduction, „Perspectives on European Politics and Society” 2012, vol. 13, nr 3, [online] https://doi.org/10.1080/15705854.2012.702570.

Cuesta Lopez V., The Lisbon Treaty's Provisions on Democratic Principles: A Legal Framework for Participatory Democracy, „European Public Law” 2010, vol. 16, nr 1.

Europejska Inicjatywa Obywatelska, Dostęp do wody i kanalizacji jest prawem cztowieka! Woda jest dobrem publicznym, nie towarem!, [online] http://ec.europa.eu/citizens-initiative/ public/initiatives/successful/details/2012/000003.

Europejska Inicjatywa Obywatelska, Jeden $z$ nas, [online] http://ec.europa.eu/citizens-initia tive/public/initiatives/successful/details/2012/000005.

37 V. Cuesta-López, A Comparative Approach..., s. 267. 
Europejska Inicjatywa Obywatelska, Odpowiedź Komisji i dziatania następcze, [online] http://ec.europa.eu/citizens-initiative/public/initiatives/successful/details/follow-up/2012/000003/pl.

Europejska Inicjatywa Obywatelska, Stop Wiwisekcji, [online] http://ec.europa.eu/citizensinitiative/public/initiatives/successful/details/follow-up/2012/000005/pl.

Europejska Inicjatywa Obywatelska, Stop Wiwisekcji, [online] http://ec.europa.eu/ citizens-initiative/public/initiatives/successful/details/2012/000007.

Europejska Inicjatywa Obywatelska, Zakaz stosowania glifosatu i ochrona ludzi i środowiska przed toksycznymi pestycydami, [online] http://ec.europa.eu/citizens-initiative/public/ initiatives/successful/details/2017/000002.

Greenwood J., The European Citizens' Initiative and EU Civil Society Organisations, „Perspectives on European Politics and Society" 2012, vol. 13, nr 3, [online] https://doi.org/10.1080 /15705854.2012.702576.

Hrbek R., National and European Political Parties and the European Citizens' Initiative, „Perspectives on European Politics and Society” 2012, vol. 13, nr 3, [online] https://doi.org/ 10.1080/15705854.2012.702579.

Komisja Europejska, Komunikat Komisji w sprawie europejskiej inicjatywy obywatelskiej „Dostęp do wody i kanalizacji jest prawem cztowieka! Woda jest dobrem publicznym, nie towarem!", Bruksela, 19 III 2014, COM(2014) 177 final.

Komisja Europejska, Komunikat Komisji w sprawie europejskiej inicjatywy obywatelskiej „Jeden $z$ nas”, Bruksela, 28 V 2014, COM(2014) 355 final.

Komisja Europejska, Komunikat Komisji w sprawie europejskiej inicjatywy obywatelskiej „Stop wiwisekcji”, Bruksela, 3 VI 2015, COM(2015) 3773 final.

Komisja Europejska, Komunikat Komisji dotyczacy europejskiej inicjatywy obywatelskiej „Zakaz stosowania glifosatu i ochrona ludzi i środowiska przed toksycznymi pestycydami", Strasburg, 12 XII 2017, C(2017) 8414 final, Annex.

Kubin T., Legitymizacja systemu instytucjonalnego Unii Europejskiej, Katowice 2014.

Kubin T., Postanowienia Traktatu Lizbońskiego a zagadnienie "deficytu demokracji” w Unii Europejskiej, „Studia Europejskie” 2010, nr 3.

Musial-Karg M., Europejska inicjatywa obywatelska - uwagi na temat roli obywateli w procesie integracji europejskiej, „Rocznik Integracji Europejskiej” 2014, nr 8, [online] https://doi. org/10.14746/rie.2014.8.6.

Rozporzadzenie Parlamentu Europejskiego i Rady (UE) nr 211/2011 z dnia 16 lutego 2011 r. w sprawie inicjatywy obywatelskiej, Dz.U. UE L 65, 11 III 2011.

Rozporzadzenie wykonawcze Komisji (UE) nr 1179/2011 z dnia 17 listopada 2011 r. ustanawiajace specyfikacje techniczne w odniesieniu do systemów zbierania deklaracji on-line na mocy rozporzadzenia Parlamentu Europejskiego i Rady (UE) nr 211/2011 w sprawie inicjatywy obywatelskiej, Dz.U. UE L 301, 18 XI 2011.

Szeligowska D., Mincheva E., The European Citizens' Initiative - Empowering European Citizens within the Institutional Triangle: A Political and Legal Analysis, „Perspectives on European Politics and Society" 2012, vol. 13, nr 3, [online] https://doi.org/10.1080/1570585 4.2012.702572.

Szewczyk M., Kilka uwag na temat instytucji obywatelskiej inicjatywy prawodawczej w Unii Europejskiej, „Przegląd Prawa Konstytucyjnego” 2012, nr 4. 
Traktat o funkcjonowaniu Unii Europejskiej (wersja skonsolidowana), Dz.U. UE C 202, 7 VI 2016.

Traktat o Unii Europejskiej (wersja skonsolidowana), Dz.U. UE C 202, 7 VI 2016.

Traktat ustanawiajacy Konstytucje dla Europy, Dz.U. UE C 310, 16 XII 2004.

Traktat $z$ Lizbony zmieniający Traktat o Unii Europejskiej i Traktat ustanawiajacy Wspólnotę Europejska, Dz.U. UE C 306, 17 XII 2007.

Vogiatzis N., Between Discretion and Control: Reflections on the Institutional Position of the Commission within the European Citizens' Initiative Process, „European Law Journal” 2017, vol. 23, nr 3-4, [online] https://doi.org/10.1111/eulj.12229.

Witkowska M., Regulacja europejskiej inicjatywy obywatelskiej przyktadem oddziatywania spoteczeństwa obywatelskiego w Unii Europejskiej, [w:] Europa dla mtodych - szansa ou d'illusion, red. A. Olejniczak, Ł. Zamęcki, Warszawa 2013.

Dr hab. Tomasz KUBIN, doktor habilitowany nauk społecznych w zakresie nauki o polityce, kierownik Zakładu Stosunków Międzynarodowych Instytutu Nauk Politycznych i Dziennikarstwa Uniwersytetu Śląskiego w Katowicach. Zainteresowania naukowe: stosunki międzynarodowe, a w szczególności integracja europejska (m.in. takie zagadnienia jak: system instytucjonalny Unii Europejskiej, Polska w Unii Europejskiej, Unia Gospodarcza i Walutowa, stosunki zewnętrzne UE, zróżnicowanie integracji w UE). 